\title{
Kulturní odkaz Miloslava Petruska
}

\author{
MIROSLAV PAULÍČEK
}

Profesor Miloslav Petrusek byl bytostně spjat s uměním. Umění bylo jedním z jeho výrazných odborných zájmů a zároveň jeho osobní zálibou. Ostatně nemá-li se o umění psát plytce a vulgárně, člověk k němu zkrátka náklonnost mít musí. Také proto (a jistě i pro jeho srovnatelnou lásku k sociologii) můžeme s klidem nahlédnout do Petruskových více než dvě desetiletí starých textů o literatuře, přičemž v nich objevíme pozoruhodnou upřímnost a ojedinělou intelektuální poctivost. Ani dnes tyto texty nejsou triviální, pomýlené, natož směšné. Právě naopak, jsou stále inspirativní a dokonce daleko svěžejší než většina současné sociologické produkce. Ani revoluční rok 1989 nezpůsobil, že bychom nad čímkoli museli přimhouřit oko; sociologická čtení beletrie, jaká Petrusek publikoval společně s Josefem Alanem v samizdatovém Sociologickém obzoru, vyšla v pozoruhodném výboru v roce 1996 [Alan - Petrusek 1996]. Takřka legendární, protože z většiny knihoven dávno ukradená, útlá knížka Sociologie a literatura svědčí o ideové pevnosti autora dokonale. Miloslav Petrusek odevzdal její rukopis v lednu 1989, kniha vyšla v roce následujícím a na jejím konci čteme v autorově ediční poznámce následující:

Při korekturách v lednu 1990 jsem s radostí zjistil, že v původním textu nemusím nic měnit úvahy o politické pornografii, o exkomunikačních procedurách ve spisovatelské obci, o krizi československé sociologie i o pseudodialektice oficiální vědy byly v původním textu v téže podobě, v níž je čtenár dostává do rukou dnes. (...) Bylo by projevem amorálního konjunkturalismu, kdybych vypustil pasus o marxismu v sociologii literatury, protože jeho postavení je opravdu takové, jak se čtenáři předkládá [Petrusek 1990: 115].

Vedle konkrétní i všeobecné reflexe literatury upíral Petrusek svou sociologickou pozornost především do oblasti, kde se standardní uměnovědci vyskytují jen zřídka a krátce, totiž na umění tzv. služebné, především totalitní. Velmi dobře si byl vědom toho, že socialistický realismus nebo umění nacistického Německa nebývají (až na výjimky) př́liš zajímavými objekty zkoumání z hlediska estetiky, zato z hlediska sociologického nesmírně. Vezmeme-li do ruky výbor Petruskových textů, který vyšel k udělení ceny Vize 97, pak je v tomto ohledu ještě zajímavější, než jaké texty v něm jsou (a že umění se více či méně týká skoro každý), jaké se do něj nedostaly; editor Jiř́i Fiala na konci uvádí hned tř̀i texty, které se služebným uměním zabývají: Umění totalitních režimů jako sociální fenomén, Československý socialistický realismus (1948-1958) a Josefína a český Slavín s podtitulem Portrét jako nástroj zobrazení člověka a manipulace kolektivní pamětí.

$\mathrm{V}$ dějinách sociologie se stalo jakousi tradicí (bohužel stále méně udržovanou), že téměř všichni velcí sociologové měli velmi vřelý vztah k umění. A nejenže měli umění v oblibě, zároveň o něm také leccos věděli. Mnozí o něm i psali (ač jsou to $\mathrm{z}$ pohledu sociologie umění postavy spíše okrajové); Georg Simmel o Beethovenovi, karikatuře nebo herectví, Pitirim Sorokin ukazoval (podobně jako Oswald Spengler) na umění „krizi našeho věku“, Max Weber psal o racionalitě v hudbě a jeho bratr Alfred třebas o Rodinovi. Také 
u nás takováto tradice vede od Masaryka přes Chalupného či Arnošta Bláhu, třeba právě až k Miloslavu Petruskovi.

Chápeme-li kulturu v nejužším slova smyslu jako kultivaci spojenou s uměním, jeví se přirozené, že kultivovat jiné může jedině člověk kultivovaný. Profesor Petrusek, jakožto zcela jedinečný pedagog, takto velmi účinně působil, a to i když přednášel o tématu jakkoliv umění vzdáleném - v teorii pole Pierra Bourdieua nalezl Vladislava Vančuru nebo v Georgu Simmelovi Tolstého Kreuzerovu sonátu. V ovzduší se přirozeně formoval dříve takřka samozřejmý předpoklad, že není možné, aby společensky či humanitně vzdělaný jedinec byl uměním netknutý a jeho kulturní znalosti začínaly a končily Harry Potterem nebo jakoukoliv upírí ságou.

Miloslav Petrusek sám sebe stále častěji označoval, co se umění týče, za „stárnoucího konzervativce“ [viz např. Petrusek 2012a], měl pro to ovšem dobrý, empiricky podložený důvod. Kupříkladu v brilantní (byt’ ne zcela doceněné) knize vydané k 660. výročí Karlovy univerzity si neodpustí povzdech nad tím, že studenti stále méně poslouchají vážnou hudbu, př́iliš nečtou klasickou beletrii a téměř vůbec nechodí na výstavy soudobého výtvarného umění [Petrusek 2008]. Petruskův kulturní konzervatismus ovšem nelze zaměňovat za staromilství. Stál naopak v jasné opozici vůči tomu, co Werich s Voskovcem nazývali „Vousaté stáříi", jež apriori odmítá vše nové a mladé už proto, že je to nové a mladé. O aktuální umění se velmi zajímal a častokrát (nejen) studentům dokázal, jak málo vědí o současném kulturním dění. Šlo mu především o toto: abychom mohli něco odmítnout, musíme to nejprve poznat. Zdravý (v tom nejlepším smyslu) přístup k umění, k němuž Miloslav Petrusek svým příkladem nabádal, by bylo možné shrnout ve třech bodech:

Zaprvé, neměli bychom odmítat to, čemu nerozumíme, jen proto, že tomu nerozumíme. Zadruhé, porozumění některým uměleckým dílům vyžaduje delší dobu, úsilí a trpělivost. Zatřetí je zároveň nutno být připraven na to, že určité umělecké dílo v sobě může skrývat toliko banalitu nebo vulgárnost.

\section{Literatura}

Alan, Josef - Petrusek, Miloslav [1996]. Sociologie, literatura, politika. Praha: Karolinum.

Petrusek, Miloslav [1990]. Sociologie a literatura. Praha: Československý spisovatel.

Petrusek, Miloslav [2008]. ... at' je stůl k pohoštění prostřený. Praha: Karolinum.

Petrusek, Miloslav [2012a]. Umění a životní styl ve společnosti zjitřených smyslů (Úvahy stárnoucího konzervativce). Kritika \& Kontext, 16 (44), s. 10-15.

Petrusek, Miloslav [2012b]. Společnost a kultura. Praha: Nadace Dagmar a Václava Havlových VIZE 97. 